\title{
Short Communication: Insulin-like growth factor 1 (IGF-1) gene polymorphisms in Madura karapan and beef cattle breed
}

\author{
DYAH PERWITASARI ${ }^{1, \boldsymbol{*}}$, ROSE IDA UMMAH ${ }^{2}$, REFA ADZANI NURJANNAH ${ }^{1,}$ ACHMAD FARAJALLAH ${ }^{1}$ \\ ${ }^{1}$ Department of Biology, Faculty of Mathematics and Natural Sciences, Institut Pertanian Bogor. Jl. Meranti, IPB University Campus Dramaga, Bogor \\ 16680, West Java, Indonesia. Tel.: +62-251-8622833, `email: witafar@gmail.com, witafar@apps.ipb.ac.id \\ ${ }^{2}$ Animal Biosciences Program, Graduate School, Institut Pertanian Bogor. Jl. Meranti, IPB University Campus Dramaga, Bogor 16680, West Java, \\ Indonesia
}

Manuscript received: 4 August 2019. Revision accepted: 29 September 2019.

\begin{abstract}
Perwitasari D, Ummah RI, Nurjannah RA, Farajallah A. 2019. Short Communication: Insulin-like growth factor 1 (IGF-1) gene polymorphisms in Madura karapan and beef cattle breed. Biodiversitas 20: 3070-3074. Madura cattle breed is one of the four existing indigenous cattle breeds (Aceh, Pesisir, Madura, and Bali) in Indonesia. This Indonesian breed derived from crossbreeding between Bos indicus (zebu) and Bos javanicus (banteng). Cattle raising in Madura focused on three purposes i.e. bull race competition (karapan), beauty contest (sonok) and meat production. Insulin-like Growth Factor 1 (somatomedin-IGF-1) is a protein that plays a key role in cell differentiation, embryogenesis, growth, and regulation of metabolism. In cattle, the IGF- 1 gene was localized on chromosome 5. Due to their role in the regulation of cell proliferation and animal growth, the IGF- $I$ and its gene are considered as candidate markers for growth rate and meat production traits. This research aimed to determine nucleotide variations in the $I G F-1$ gene among Madura karapan and beef cattle. PCR amplification of $I G F-1$ gene was conducted using a pair of primers. Amplicon was sent to commercial DNA sequencing company $\left(1^{\text {st }}\right.$ Base) to perform DNA sequencing analysis. The size of $I G F-1$ gene was approximately 762 bp consisted of intron 3, exon 4, and intron 4. Sequence data were analyzed using MEGA 7 to identify the presence of nucleotide variation. Bos indicus (NC032654) was used as a reference sequence. The results showed no polymorphism was observed in intron 3 and exon 4 of Madura karapan and beef cattle breed. We determined G491A point mutation in intron 4. In conclusion, IGF- 1 could not be able to be used as a genetic marker to differentiate karapan and beef cattle and furthermore morphological characteristics still can be applied as a standard for selection.
\end{abstract}

Keywords: $I G F-1$, intron 4, Madura cattle breed, point of mutation

\section{INTRODUCTION}

The domestication of species along with the history of migration, selection, and adaptation has resulted in a wide variety of local breeds (Groeneveld et al. 2010). Indonesian local cattle have experienced a selection of tropical climate and adapted to the local environment (Sutarno and Setyawan 2015). Madura cattle originated from crossbreeding of zebu (Bos indicus) and banteng (Bos javanicus) (Nijman et al. 2003). Madura cattle have a good meat quality and excellent adaptive to hot climate, limited feed quality, and parasite attack (Payne and Hodges 1997). Madura cattle raised for three different purposes, namely karapan, sonok, and beef. Karapan cattle are male Madura cattle for bull race competition having excellent agility and speed characteristics. Sonok cattle are female Madura cattle for beauty contest which have an eased handling and beautiful characteristics. Karapan and sonok cattle are well maintained to have good posture, body condition, ideal size, and good growth performance (Maylinda et al. 2017; Kutsiyah 2012). Common Madura cattle known as beef cattle have no specific characteristics. Local farmers perform selection in karapan and beef cattle based on performance and morphological characters. Advanced in
DNA molecular techniques can be used to improve the accuracy and efficiency of conventional selection using genetic markers. Therefore, genetic diversity which significantly affecting economically traits is important and useful information. IGF-1 has been demonstrated to contribute to genetic variation in traits such as body size, food conversion efficiency, milk production, fat deposition as well as carcass fatness, live and carcass weight, and average daily gain in cattle (Davis and Simmen 2000; Johnston et al. 2001; Mullen et al. 2011). To date there is only limited published information on IGF-1 polymorphisms of indigenous livestock, to distinguish both Karapan and beef cattle breed particularly.

Insulin-like growth factor $1(I G F-1)$ or somatomedin C, is a member of a major growth-promoting signaling system (Stratikopoulos et al. 2008). The IGF-1 gene acts in various physiological and metabolic functions, where $I G F-1$ and growth hormone $(\mathrm{GH})$ involved in the somatotropic axis. The IGF- 1 is a mediator of many biological processes, for example, it increases the absorption of glucose, stimulates myogenesis, and intervenes in the synthesis of DNA, protein, RNA and cell proliferation (Reyna et al. 2010). The IGF- $I$ also plays an important role in various aspects of muscle growth and development (Davis and Simmen 
1997). Due to its biological function, $I G F-1$ is considered as a major candidate gene for economically important traits of animal husbandry.

The $I G F-1$ is produced primarily by the liver, from which $I G F-1$ is released into the bloodstream and acts as an endocrine hormone. The $I G F-1$ is synthesized in many extrahepatic tissues, where it functions in autocrine and paracrine fashion (Le Roith 1997). The bovine $I G F-1$ gene is located on chromosome 5 , consists of 6 exons and 5 introns (Rotwein 2017). Studies of single nucleotide polymorphism (SNP) in $I G F-1$ gene revealed that it has been associated with growth (Ge et al. 2001), milk production (Mullen et al. 2011), and carcass traits in cattle (Curi et al. 2005; Islam et al. 2009).

The identification of nucleotide variations in Madura cattle breed is expected to determine genetic selection in karapan and beef cattle. This research aimed to determine nucleotide variations among Madura karapan and beef cattle breed, to answer the question of whether or not the selection in karapan breed cattle affecting the $I G F-1$ gene or it caused by the talent scouting process alone.

\section{MATERIALS AND METHODS}

\section{Samples}

Blood samples were collected from the original regions of Madura native cattle breeds. The fresh blood was collected using cotton pads from the buttocks wound caused by the jockeying jerking immediately after the race was over. Karapan breed cattle samples were the top ten of the 2017 Presidential Cup Karapan in Pamekasan Madura $(\mathrm{N}=10)$. Beef cattle blood samples preserved in $90 \%$ ethanol are laboratory collection from 2009-2017 obtained from several regions in Madura $(\mathrm{N}=10)$.

\section{DNA isolation, PCR amplification, and DNA sequencing}

Genomic DNA was extracted with a genomic DNA extraction kit (Geneaid DNA isolation kit) according to the instructions provided in the manual. The quantity and quality of DNA were controlled using NanoDrop 2000 spectrophotometer (Thermo Scientific, USA). A total of twenty DNA samples were analyzed for polymorphisms in one exon (exon 4) and two introns (introns 3 and 4) of insulin growth factor $1(I G F-1)$ gene. The primers were designed based on IGF-1 gene of Bos indicus (GenBank Acc. no. NC_032654) using Primer3 (http://bioinfo.ut.ee/ primer3-0.4.0/ primer3/). The primers consisted of forward (5'ACCAGTGCTGTCTTCTGCATC) and reverse (5'AGTCACCCTGTAGGGAAGGAA) (Figure 1). The PCR amplifications were performed in reaction mixtures of $25 \mu \mathrm{l}$ containing $12.5 \mu \mathrm{l}$ of $1 \times$ GoTaq ${ }^{\circledR}$ Green Master Mix, $0.5 \mu \mathrm{M}$ of each primer and 25-75 ng of genomic DNA. Amplification was performed using BIOMETRA $T$ Gradient Thermocycler. Cycling conditions were as follows: initial denaturation at $95^{\circ} \mathrm{C}$ for $1 \mathrm{~min}$ followed by 30 cycles $95^{\circ} \mathrm{C}$ for $1 \mathrm{~min}$, annealing at $56^{\circ} \mathrm{C}$ for $1 \mathrm{~min}$, elongation at $72^{\circ} \mathrm{C}$ for $2 \mathrm{~min}$, and a final extension at $72^{\circ} \mathrm{C}$ for $2 \mathrm{~min}$. The amplicon was directly analyzed via electrophoresis on a $6 \%$ polyacrylamide gel stained with silver (Byun et al. 2009). The amplicons were purified and sequenced commercially by First BASE Laboratories (Malaysia).

\section{Sequence analysis}

Sequence data were manually checked for quality including background noise, peak intensity, and accuracy using BioEdit version 7.2.6 (Hall 1999). The data sequences are aligned with the $I G F-1$ gene segment of Bos indicus as the reference sequence (GenBank Acc. No. NC_032654) using a built-in CLUSTALW in MEGA version 7.0 (Kumar et al. 2016). To control the result of multiple alignments on nucleotide sequences data, the multiple alignments were also performed on amino acid sequences based on the Standard Genetic Code Table. The amino acid sequence alignment analyses intended to determine the exon and intron according to sequence reference.

\section{RESULTS AND DISCUSSION}

\section{IGF-1 gene amplification}

Intron 3, exon 4, and intron 4 of $I G F-1$ gene in karapan and beef breed cattle were successfully amplified using certain pairs of primer (AF553 and AF554). Amplicon length was $762 \mathrm{bp}$ approximately. Nucleotide position number was determined using $B$. indicus (NC032654) as sequence reference. Forward primer (AF553) attached to nucleotide position of 57783 in intron 3 region, while reverse primer attached to nucleotide position 58544 in intron 4. The sequence result of $I G F-1$ gene in Madura cattle breed was $762 \mathrm{bp}$, consisted of intron 3 (101 bp), exon 4 (168 bp), and intron 4 (492 bp) (Figure 1).

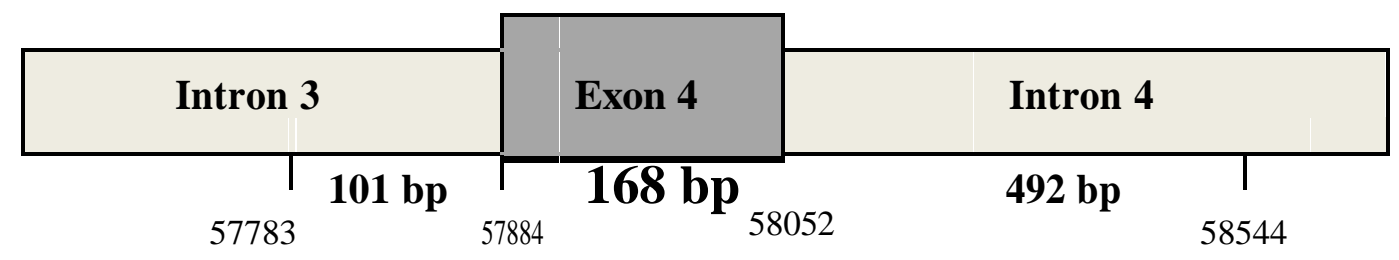

Figure 1. Primers position (AF553 and AF554) on nucleotide position 57783 in intron 3, exon 4, and intron 4 of IGF-1 B. indicus (GenBank Acc no. NC032654) 


\section{Nucleotide polymorphisms analysis}

There were four types of sequencing data result, Madura karapan and beef cattle with single and double bands. Alignment towards Bos indicus (GenBank Acc no. NC032654) revealed no nucleotide variation determined in intron 3 and exon 4. However, the mutation was found in intron 4. Intron 4 mutation was substitution exchanging Guanine into Adenine at nucleotide position $491 \mathrm{bp}$ on karapan 2 and beef cattle 1 (Figure 2).

Double peaks were validated in the chromatograms of certain sequences generated in this study. Only chromatograms with no background bias were used. Position in the chromatograms where double peaks were visible was represented as karapan 1 and beef cattle 2 (Figure 3). Sequencing of intron 4 in karapan 1 and beef cattle 2 revealed double peaks in position 491 (A491G). This can be due to allelic sequence heterozygosity. Alignment of these sequences, together with sequence $B$. indicus (GenBank Acc no. NC032654) were used as a baseline to define potential polymorphism.

\section{Amino acid translation}

Amino acid translation performed using MEGA6 after completing the alignment of intron 3 , exon 4 , and intron 4 of IGF-1 gene. Amino acid translation of exon 4 of $I G F-1$ gene resulted in 56 codons. The first codon was determined using B. indicus (NC032654) as sequence reference. Transition mutation of G491A in intron 4 was not changed the amino acid. As there was no nucleotide variant in the coding region of exon 4 , there was no amino acid alteration found in this region (Figure 4).

\section{Discussion}

IGF-1 gene amplification using primer AF553 and AF554 in karapan and beef cattle yielded a 762 bp length amplicon. IGF-1 gene on bovine was located on chromosome 5, consisted of 6 exons and 5 introns (Rotwein 2017). Three regions were successfully amplified, which were part of intron 3, exon 4, and intron 4. Forward primer (AF553) attached to intron 3 while reverse primer (AF554) attached to intron 4. Alignment between karapan and beef cattle with Bos indicus (NC032654) showed no nucleotide variants found in part of intron 3 and exon 4. Only one nucleotide variant of G491A found in intron 4 of $I G F-1$ gene. This might reflect that $I G F-1$ gene is highly conserved among vertebrates (Upton et al. 1981). The nucleotide variant of G/A which was shown by the presence of double peaks on chromatogram indicated the presence of allelic heterozygosity in one position. One allele has Guanine $(G)$ and the other has Adenine (A).

The intron is a non-protein coding region that normally removed by RNA splicing during maturation of RNA product (Birge 1981). Mutations in introns usually do not affect due to intron sequence is spliced before mRNA translation. A mutation that causes intron to be incorrectly spliced out could result in the production of an abnormal protein. Fuqua et al. (2012) reported that heterozygous mutation in intron 4 induced the splicing out of exon 4 , leading to predicted frameshift and protein truncation in the large kindred of familial short-stature. Furthermore, the study of Gui et al. (2018) depicted that intronic SNPs do not alter amino acid sequences, however, these polymorphisms significantly influence the growth traits of Qinchuan cattle. Several nucleotide polymorphisms studies have been reported in the various breed of cattle. A novel single nucleotide polymorphism (SNP) in exon 4 of $I G F-1$ gene caused by the T/C transition associated directly with birth, weight, weaning weight, and average daily weight gain in Bali cattle (Maskur et al. 2010). Nine SNPs in the promoter region, 3'UTR, and within introns of IGF-I associated with performance in Holstein-Friesian dairy cattle (Mullen et al. 2011). SNP in the promoter region (IGF1/SnaBI) associated with weaning weight, weaning weight adjusted to 20 days, and pre-weaning weight gain in Charolais breed (Reyna et al. 2010).

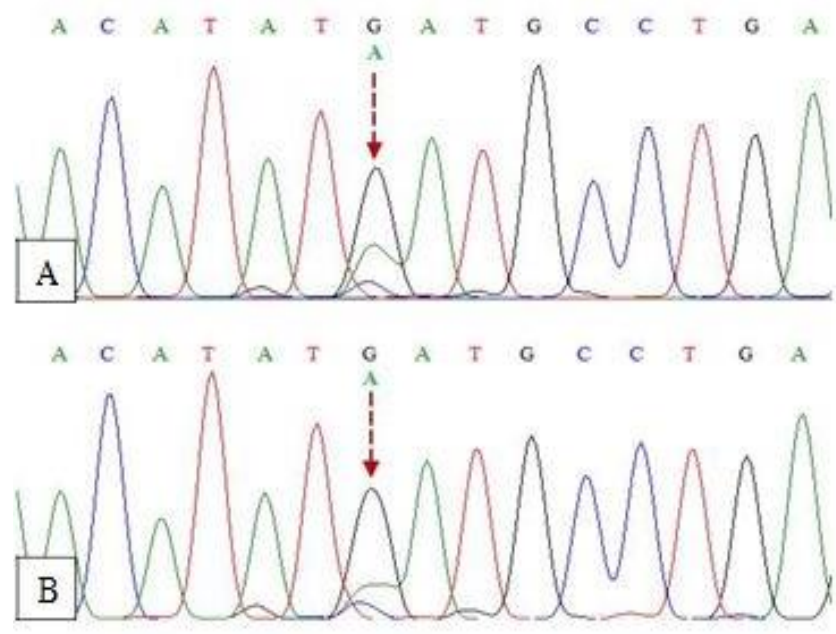

Figure 3. Sequence chromatogram of nucleotide variations. Chromatogram of sequences generated from Madura cattle breed, where the position indicated with an arrow shows the presence of a double peak of G491A in Karapan 1 (A) and Beef cattle 2 (B)

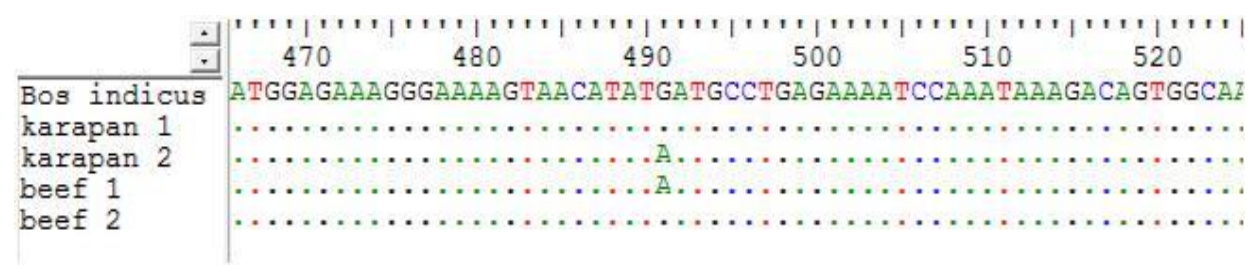

Figure 2. Sequence alignment of intron $4 I G F-1$ gene in Madura karapan, beef cattle breeds, and B. indicus (GenBank Acc no. NC032654) 


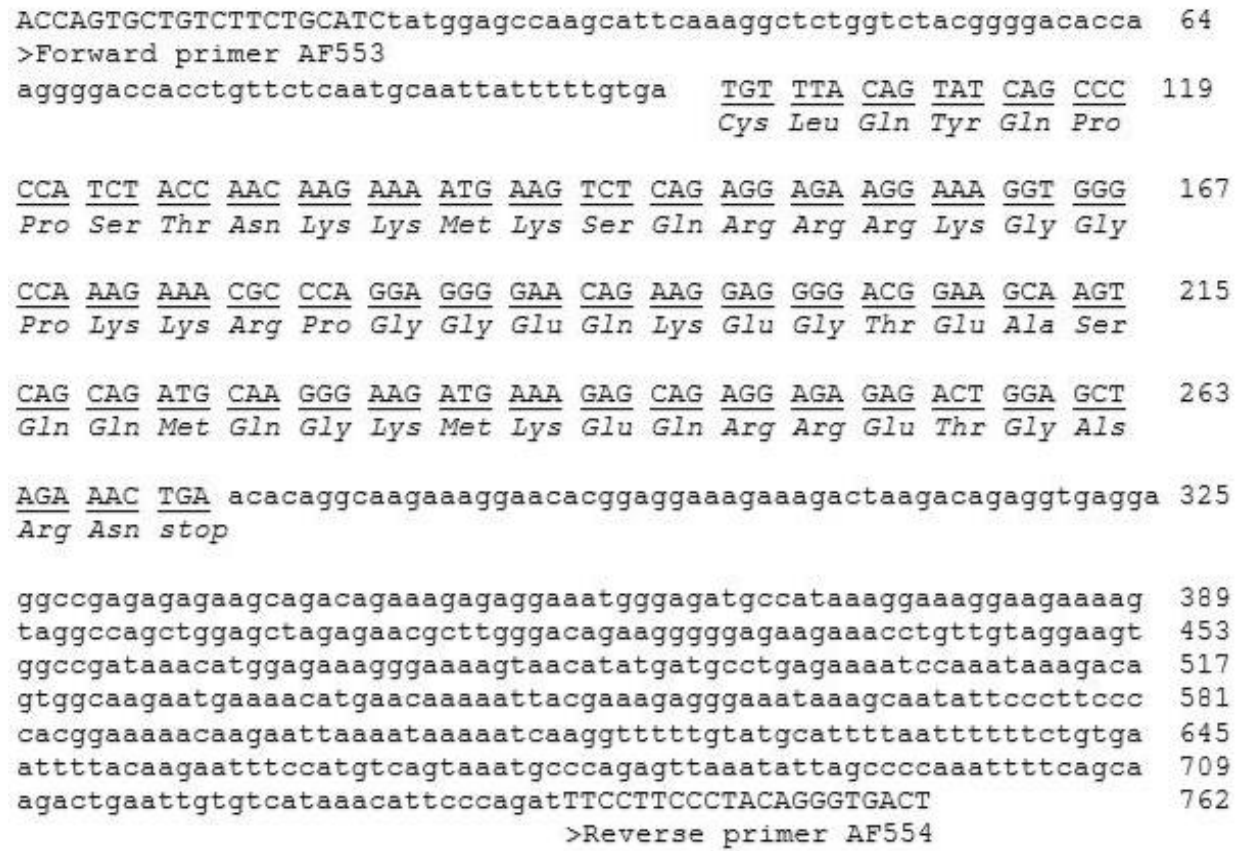

Figure 4. The nucleotide sequence of the intron 3 IGF-1 gene started from forward primer AF553. Exon 4 started from the underlined codon, alongside with the result of amino acid translation. Intron 4 started after stop codon and ended by reverse primer AF554. Amino acid translation determined using B. indicus (GenBank acc no. NC032654) as sequence reference

Hitherto, the selection of three categories of Madura cattle breeds was performed by local farmers without any standard operational procedure. Local farmers observed the ability of karapan cattle since they were a calf (4 months of age) and continued by daily exercise to be able to participate in bull race competition ( 2 years at minimum age). An active karapan cattle were prohibited to be used as agricultural working and breeding animals. Special treatments were provided, such as taking a bath every day, sunbathe in the morning, massage, furthermore, nutritious fodder and herbs were added to its food. Karapan cattle consumed 10-20 eggs per day, then increased the numbers to 80-100 eggs when closed to the due date of competition (Kosim 2007). Karapan cattle that no longer participated in bull race competition could be categorized as beef cattle. The result of the nucleotide variant of $I G F-1$ gene depicted that both karapan and beef cattle have identical G491A transitions in intron 4. Accordingly, IGF-1 cannot be used as a genetic marker to differentiate karapan and beef cattle. Although both cattle were indistinguishable using IGF-1 gene, morphological characteristics still can be applied as a standard for selection. Beef cattle have outward horn characters, while karapan cattle showed peculiar characteristics such as a basin along the backline forming back muscle due to intensive exercised (Ummah, 2018). Besides, sonok cattle have bright circle eyes, pastern, and humped. Sonok also has higher shoulder height and bigger hump size than that in beef cattle (Lutvaniyah, 2017).

\section{ACKNOWLEDGEMENTS}

We are grateful to all members of the research entitled Genetic Profile of Madura cattle that contributed to sample collection. The study was funded by the Ministry of Research and Technology, Higher Education within the World-Class Research (WCR) program (Grant No. 1538/IT\#.L1/PN/2019) to D. Perwitasari.

\section{REFERENCES}

Birge EA. 1981. Bacterial and Bacteriophage Genetic. Springer, New York.

Byun SO, Fang Q, Zhou H, Hickford JGH. 2009. An effective method for silver-stain staining DNA in large numbers of polyacrylamide gels. Anal Biochem 381:174-175.

Curi RA, De Oliveira HN, Silveira AC, Lopes CR. 2005. Association between $I G F-1, I G F-1 \mathrm{R}$, and GHRH gene polymorphisms and growth and carcass traits in beef cattle. Livestock Prod Sci 94 (3): 159-167.

Davis ME, Simmen RC. 2000. Genetic parameter estimates for serum insulin-like growth factor-I concentration and carcass traits in Angus beef cattle. J Anim Sci. 78: 2305-2313.

Fuqua JS, Derr M, Rosenfeld RG, Hwa V. 2012. Identification of a novel heterozygous IGF1 splicing mutation in a large kindred with familial short stature. Horm Res Paediatrics 78: 59-66.

Ge W, Davis ME, Hines HC, Irvin Km, Simmen RC. 2001. Association of a genetic marker with blood serum insulin-like growth factor-1 concentration and growth traits in Angus cattle. J Anim Sci 79 (7): 1757-1762.

Groeneveld LF, Lenstra JA, Eding H, Toro MA, Scherf B, Pilling D, Negrini R, Finlay EK, Jianlin H, Groeneveld E, Weigend S, Globaldiv consortium. 2010. Genetic diversity in farm animals-a review. Anim Gen. 41 (1): 1-26. 
Gui LS, Wang ZY, Jia JL, Zhang CT, Chen YZ, Hou SZ. 2018. IGF-1 gene polymorphisms influence bovine growth traits in Chinese qinchuan cattle. Kafkas Univ Vet Fak Derg 24 (3): 387-392.

Hall TA. 1999. Bioedit: a user-friendly biological sequence alignment editor and analysis program for Windows 95/98/NT. Nucl Acids Symp Ser. 41: 95-98.

Islam KK, Vinsky M, Crews RE, Okine E, Moore SS, Crews Jr DH, Li C. 2009. Association analysis of a SNP in the promoter of IGF1 with fat deposition and carcass merit traits in hybrid, Angus, and Charolais beef cattle. Anim Gen 40: 766-769.

Johnston, DJ, Herd RM, Reverter A, Oddy VH. 2001. Heritability of IGFI in beef cattle and its association with growth and carcass traits. Proc Assoc Adv Anim Breed Genet. 14: 163-166.

Kosim M. 2007. Kerapan Sapi; "Pesta" Rakyat Madura (Perspektif Historis-Normatif). Karsa 9 (1): 68-76.

Kumar S, Stecher G, Tamura K. 2016. MEGA7: Molecular Evolutionary Genetics Analysis version 7.0. Mol Biol Evol 33 (7): 1870-1874

Kutsiyah F. 2012. Analisis pembibitan sapi potong di pulau madura. Wartazoa 22 (3): 113-126.

Le Roith D. 1997. Insulin-like Growth Factors. Seminars in Medicine of the Beth Israel Deaconess Medical Center. New England J Med 336 (9): 633-640.

Lutvaniyah S. 2017. Analisis fenotipe sapi sonok dan sapi pedaging Madura [Thesis]. Institut Pertanian Bogor, Bogor. [Indonesian]

Maskur, Arman C, Sumantri C, Gurnadi E, Muladno. 2012. A novel single nucleotide polymorphism in exon 4 of insulin-like growth factor-1 associated with production traits in Bali cattle. Media Peternakan 35 (2): 96-101.

Maylinda S, Nugroho H, Busono W. 2017. Phenotypic characteristics of local cattle in Madura Island. AIP Conf Proc 1844, 060002. DOI: 10.1063/1.4983442.

Mullen MP, Berry DP, Howard DJ, Diskin MG, Lynch CO, Giblin L, Kenny DA, Magee DA, Meade KG, Waters SM. 2011. Single nucleotide polymorphisms in the insulin-like growth factor $1(I G F-1)$ gene are associated with performance in Holstein-Friesian dairy cattle. Front Gen 2 (3):1-9.
Mullen MP, Lynch Co, Waters SM, Howard DJ, O'Boyle P, Kenny DA, Buckley F, Horan B, Diskin MG. 2011. Single nucleotide polymorphisms in the growth hormone and insulin-like growth factor1 genes are associated with milk production, body condition score and fertility traits in dairy cows. Gen Mol Res 10 (3): 1819-1830.

Nijman IJ, Otsen M, Verkaar ELC, de Ruijter C, Hanekamp E, Ochieng JW, Shamshad S, Rege JEO, Hanotte O, Barwegen MW, et al. 2003. Hybridization of banteng (Bos javanicus) and zebu (Bos indicus) revealed by mitochondrial DNA, satellite DNA, AFLP and microsatellites. Heredity 90: 10-16.

Payne WJA, Hodges J. 1997. Tropical Cattle: Origins, Breed, and Breeding Policies. Blackwell Science Ltd., Oxford, UK.

Reyna XF de la Rosa, Montoya HM, Castrellon VV, Rincon AMP, Bracamonte MP, Vera WA. 2010. Polymorphism in the $I G F-1$ gene and their effect on growth traits in Mexican beef cattle. Genet Mol Res 9 (2): 875-883.

Rotwein P. 2017. Diversification of the insulin-like growth factor 1 gene in mammals. PLoS ONE 12 (12): e0189642. DOI: 10.1371/journal.pone.0189642

Stratikopoulos E, Szabolcs M, Dragatsis L, Klinakis A, Efstratiadis A. 2008. The hormonal action of IGF1 in postnatal mouse growth. Proc Natl Acad Sci USA 106 (49): 19377-19382.

Sutarno, Setyawan AD. 2015. Review: Genetic diversity of local and exotic cattle and their crossbreeding impact on the quality of Indonesian cattle. Biodiversitas. 16 (2): 327-354.

Tamura K, Stecher G, Peterson D, Filipski A, Kumar S. 2013. MEGA6: Molecular Evolutionary Genetics Version 6.0. Mol Biol Evol 30 (12): 2725-2729.

Ummah RI. 2018. Differensiasi tipe sapi Madura berdasarkan karakter morfologi dan variasi nukleotida pada gen drd1 Madura [Thesis]. Institut Pertanian Bogor, Bogor. [Indonesian]

Upton Z, Yandell CA, Degger BG, Chan SJ, Moriyama S, Francis GL, Ballard FJ. 1998. Evolution of insulin-like growth factor-I (IGF-1) action: in vitro characterization of vertebrate $I G F-1$ proteins. Comp Biochem Physiol Biochem Mol Biol. 121 (1): 35-34. 